\title{
The current case law of the European Court of Human Rights on privacy: challenges in the digital age
}

\author{
Dr Özgür Heval Çınar
}

School of Law and Criminology, University of Greenwich, London, UK

\begin{abstract}
The right to privacy is one of the rights enshrined in international human rights law. However, with the increasing digitalisation of modern life, protecting one's privacy has become more complicated. Both state and non-state organisations make frequent interventions in citizens' private lives. Legislations exist to ensure such interventions are carried out proportionately and with the permission of the relevant authorities. In this article a close look will be taken at Article 8 of the European Convention on Human Rights, its historical origins, definition and scope. The article will also examine current case law of the European Court of Human Rights in the light of the current developments in the digital world.
\end{abstract}

\section{KEYWORDS}

Rightto privacy; private life; personal data; European

Convention on Human

Rights; European Court of Human Rights

\section{Introduction}

Members of the human race have, since time immemorial, shared common spaces with other human beings, while also possessing a personal and private life. The term private life is used to denote a private space which a person claims possession of and permits others to enter. Hence, private life provides us with protection against arbitrary and baseless interventions by state and other organisations. It is the individual who has control of the space, into which s/he does not want others to pry. ${ }^{1}$ The origin of this right lies in human dignity and is the basis of all human rights. The important thing is to enhance the rights of individuals and their standard of living in order that they may achieve their aspirations. This right has a broad-spectrum including elements such as physical space, home, family life and correspondence. It has consequently been protected by international human rights law and by the domestic legislation of many countries.

Private life is a fundamental right that deserves universal respect by every state. It achieved recognition in international human rights law after the Second World War. However, since this right is a complex one it is covered in various areas of law. These include property rights, health, insurance and financial law.

Rapid technological developments in the twenty-first century have led to increased surveillance of individuals' private lives. Monitoring can take place by means of smartphones and computers and data on consumers is easily obtained from search engines, social media and credit card use. This monitoring is in general carried out by states on security grounds. 
In this article, apart from taking a brief look at the antecedents of private life, the definition and range of this right will be put under the microscope. An examination of the definition of this right in Article 8 of the European Convention on Human Rights ('ECHR' and/or 'the Convention') will also be undertaken. Hence, this article will explore in the light of the current case law of the European Court of Human Rights ('ECtHR' and/or 'the Court') to what degree the right to privacy, one of the most important freedoms for the existence of human dignity, has been restricted in the digital world, and examine the challenges facing these freedoms. Indeed, the reason it is different to many previous studies is that it makes a detailed examination of ECtHR judgments relating to developments in the digital world, something that is absent from the literature. Thus, this article will look closely at it will make a major contribution to the literature. Moreover, the article will endeavour to find answers to the following questions: How in private life can the balance be struck between the gathering of personal data and the maintainance of security? What does the term personal data mean? In what situations may it be valid to limit this freedom? What are the threats to this freedom in our lives which digital devices dominate? By whom are these threats being created? What is the attitude of the ECtHR towards these threats?

\section{Definition and history of the right to privacy}

The term private life is derived from the Latin word privatus meaning 'separate from public life, belonging to the individual'.2 The term private life is sometimes used as a synonym for the concept of intimate relations. However, this is not correct, as private life is the 'private space' that a person shares with those they trust, that they keep separate from all other persons and do not want others to learn about. This space is not one included in an individual's private space, but one which s/he also shares with close family members and friends. In short, it embodies not only a person's private space, but also a part of non-private space. ${ }^{3}$

The origins of this right can be observed in primitive communities. In communities where no dividing walls or screens existed 'imaginary walls' were used to create abstract private areas. The Yagua people in the northeast of Peru who live in houses without inner walls or screens turn and face the wall of the house when they wish to have a private space. When they do this, the message they convey is that the are not present in that space. In Europe, with the collapse of the Western Roman Empire and the emergence of powerful tribes, people looked to have more protected houses, and privacy gained in significance. ${ }^{4}$ The increasing importance of privacy was accompanied by protection being introduced for the inviolability of domicile and the right to privacy. For instance, the 'Justices of the Peace Act' of 1361 envisaged the arrest of those who eavesdropped or followed other people..$^{5}$ With urbanisation in the 16th century, the beginning of industrialisation and invention of the printing press, steps were taken to protect privacy. In 1710 it was made illegal to open letters in England without official permission. In the nineteenth century in the United States of America debates took place regarding respect for private life. Following the Second World War there was increasing international interest in this subject. Technological advances in the twenty-first century have made it abundantly clear that there is an urgent need for this right to be given serious protection. ${ }^{6}$ 
While in certain international documents, for instance, Article 8 of the Convention, the term 'private life' is used, in Article 12 of the Universal Declaration of Human Rights (UDHR) and Article 17 of the International Covenant on Civil and Political Rights (ICCPR) the term 'privacy' is used. In short, the term private life means the right to privacy. Furthermore, in international documents there is not a clear, concise definition of private life. Article 8 of the ECHR contains no definition at all, and in the ECtHR judgment Niemietz v. Germany was the following:

The Court does not consider it possible or necessary to attempt an exhaustive definition of the notion of 'private life'. However, it would be too restrictive to limit the notion to an 'inner circle'...

There are also problems regarding the meaning of private life and uncertainty over establishing its scope in the literature. Arthur Miller felt it was a difficult concept to define on account of a troubling ambiguity and inclination to vanish. ${ }^{8}$ And Julie C. Innes said: 'Exploring the concept of privacy resembles exploring an unknown swamp... We turn to the legal and philosophical literature on privacy in the hope of gaining a foothold. Instead, we find chaos; the literature lacks an accepted account of privacy`s definition and value'. ${ }^{\prime}$

Nevertheless, difficulties encountered in defining the right does not mean it is of no importance or does not exist. This right is crucial as regards human dignity, freedom and democracy and a prerequisite for a democratic society. It has been described as the most fundamental of all freedoms, offering an individual the opportunity to be creative and ensuring they can engage in social relations with others, while also protecting autonomous life and physical tranquillity. ${ }^{10}$ The Special Rapporteur to the Human Rights Council said the following in a report in 2016:

Recognizing that the right to privacy can enable the enjoyment of other rights and the free development of an individual's personality and identity, and an individual's ability to participate in political, economic, social and cultural life, and noting with concern that violations or abuses of the right to privacy might affect the enjoyment of other human rights, including the right to freedom of expression and to hold opinions without interference, and the right to freedom of peaceful assembly and association ... ${ }^{11}$

It is evident how this right has been infringed, both by state and non-state bodies, especially given recent technological advances. The United Nations (UN) Special Rapporteur noted in 2016 that ten per cent of citizens worldwide had been the victim of human rights violations regarding their personal data. Moreover, this right has yet to be provided with legal protection by more than $70 \mathrm{UN}$ member states. ${ }^{12}$

\section{Scope of the right to privacy (Article 8)}

The right to privacy is protected in international human rights law. The main international documents have all safeguarded this right. For instance, article 12 of the UDHR, article 17 of the ICCPR, article 8 of the ECHR, articles 7 and 8 of the European Union (EU) Charter of Fundamental Rights, article 5 of the American Declaration of the Rights and Duties of Man (ADRDM) and article 11 of the American Convention on Human Rights (ACHR) are the relevant provisions. While the above articles answer the question as to why the right to privacy needs protection, no answers are provided as regards when, how and by whom this freedom should be safeguarded. ${ }^{13}$ 
The Council of Europe is one of the most important institutions in Europe. It was established after the Second World War, guaranteeing rights and freedoms in the Convention, which came into force on 3 September 1953. In order for these rights and freedoms to be guaranteed the ECtHR was created.

Article 8 of the ECHR states:

(1) Everyone has the right to respect for his private and family life, his home and his correspondence.

(2) There shall be no interference by a public authority with the exercise of this right except such as is in accordance with the law and is necessary in a democratic society in the interests of national security, public safety or the economic wellbeing of the country, for the prevention of disorder or crime, for the protection of health or morals, or for the protection of the rights and freedoms of others.

A general framework regarding this freedom is outlined in the first paragraph of this article. The freedom in question provides protection for an individual's private life and also to family life, the home and confidentiality of correspondence. In the second paragraph, it is stated that these rights are not absolute and that in certain circumstances the public authorities may intervene. In the chapters below an examination will be made as to in which circumstances such interventions may take place.

Private life is a concept too broad to be defined with all its aspects. ${ }^{14}$ This concept cannot be expressed through the narrow concept of privacy and is interpreted by the ECtHR in a dynamic way, taking into consideration social and technological developments. This right incorporates a sphere that provides everyone with the opportunity to develop a free personality. In Niemitz v Germany the Court stated:

[private life] would be too restrictive to limit the notion to an "inner circle" in which the individual may live his own personal life as he chooses and to exclude therefrom entirely the outside world not encompassed within that circle. Respect for private life must also comprise to a certain degree the right to establish and develop relationships with other human beings. ${ }^{15}$

When ECtHR judgments are examined, it will be seen that those concerning private life are in three categories. The first category is one that may be called that of 'physical, psychological or moral integrity'. This includes issues such as victims of violence, reproductive rights, forced medical treatment and compulsory medical procedures, mental illness, health care and treatment, end of life issues, disability issues, issues concerning burial, environmental issues, sexual orientation and sexual life and professional or business activities. The second category is that of identity and autonomy'. This category incorporates the right to personal development and autonomy, right to discover one's origins, religious and philosophical convictions, desired appearance, right to a name/identity documents, gender identity, right to ethnic identity, statelessness, citizenship and residence and marital/parental status. The last category is under the heading 'privacy'. This category includes the right to one's image and photographs, the publishing of photos, images and articles, protection of individual reputation and defamation, data protection, right to access personal information, information about one's health, file or data gathering by security services or other organs of the State, police surveillance and stop and search 
police powers and privacy during detention. ${ }^{16}$ In these categories 'privacy' constitutes the main element of this article, and below a more detailed examination of this topic within the framework of ECtHR judgments will be made. However, before the term privacy is explored, it would be fruitful to examine briefly the terms of 'family life', 'home' and 'correspondence' in the light of the ECtHR's case law.

Family life, too, has undergone many social and legal changes since the Convention came into force in 1953, and the Court has interpreted this concept according to contemporary circumstances. It has adopted a flexible approach, taking into consideration the diversity of modern family arrangements, the consequences of divorce and developments in medicine. ${ }^{17}$ The first issue the Court examines is to establish whether the persons involved in the case have close personal links. For instance, in the event of it being proved to be legal and natural, a family based on marriage and the relationship of this family to the children of this family are within the scope of this right. However, it has been made clear that if the relationships of unmarried persons living together are stable, they will be accepted within the concept of family. ${ }^{18}$ But in order to talk about a concept of family it is not necessary for the persons to be living together. Hence, people who are not living together on account of divorce, separation or wish are also within the scope of this right. ${ }^{19}$ While the Court in general seeks a blood tie between persons, it has on one occasion handed down a judgment finding that those without a blood tie may have a family life. For example, in the case of $X, Y$ and $Z v$ the United Kingdom $(U K)$ the Court found that a femal-to-male transsexual who had a child using AID (artificial insemination) had set up a family life. ${ }^{20}$ It noted that a co-habiting same sex couple in a stable relationship could have the same kind of family life as a heterosexual couple. $^{21}$

Another right safeguarded within the scope of this article pertains to home. ${ }^{22}$ The term 'home' is an 'autonomous' concept. ${ }^{23}$ The meaning of autonomous is as follows: the way states that are signatories to the Convention define the concept of home in their domestic legislation and what are classified as dwellings are not binding for the ECtHR. According to its case law, home is the physically defined area where private life and family life develops. ${ }^{24}$ As regards whether a place will be accepted by the ECtHR as a home, it uses a factual criterion as to whether there are 'sufficient and continuous links with that place'. For instance, it is not necessary that the persons own the place in question. ${ }^{25}$ The Court has found a property owned by a person to be a home if they continually intend to return there and if they have connections to the property in question. ${ }^{26}$ Furthermore, workplaces have also been put into the scope of home, with 'caravan', 'bungalow', 'summer house' and 'second homes' also being accepted as 'home'. ${ }^{27}$ Even a hotel room may be accepted as a home as long as 'sufficient and continuing links' have been established. ${ }^{28}$

Lastly, the right to correspondence is safeguarded by Article 8. A person's right to respect for their correspondence is a right to correspond with others without interruption or censor. ${ }^{29}$ This includes an individual's communication with others by means such as letter, electronic mail, telephone, internet, telex or fax. ${ }^{30}$ Apart from individuals, legal entities are also able to benefit from this right. ${ }^{31}$ In Bernh Larsen Holding AS and others v. Norway three Norwegian companies received a demand from the tax authorities to provide a copy of all their data from a joint server. The companies made an application to the Court claiming a violation of paragraph 1 of Article 8 of the Convention had 
taken place. The ECtHR examined the application within the framework of the right to respect for the home and correspondence right, finding there had been an intervention in both rights, but reaching the conclusion that these rights had not been violated. ${ }^{32}$ Moreover, conversations that are the subject of correspondence do not in any case have to be about private life, as professional topics are also within the scope of this protection. For instance, a lawyer's conversation with a client may come within the scope of article $8 .^{33}$

\section{Positive and negative obligations under Article 8}

Since the rights in this article are in the category of 'qualified right', the state authorities are legally permitted to interfere in certain situations. In order for restrictions to be placedon this freedom there are three stage tests that must be applied:

(1) Any state intervention must be legal (in accordance with law). This includes statutes, decree laws, codes, regulations and court judgments. ${ }^{34}$ The legislation in question should be sufficiently precise and incorporate a provision to protect against arbitrary measures by the authorities. ${ }^{35}$ In other words, the law in question should contain foreseeability and accessibility safeguards against arbitrariness in implementation. ${ }^{36}$

(2) One of the legitimate aims cited in Article 8(2), that is, national security, public safety or the economic well-being of the country, the prevention of disorder or crime, the protection of health or morals, or the protection of the rights and freedoms of others, should be used as justification.

This is a question asked by the Court at the second stage. Since it is up to the respondent State to make clear the purpose or purposes of the interference, and the fact that reasons that may be cited for any interference are so all-encompassing - for instance, in the interests of national security - a State is usually able to construct a reasonable justification to support interference. Applicants very often claim that the justification asserted by the State is not the 'real' grounds for the interference at issue, but the Court has not been open to accepting such claims. On the contrary, the Court has generally not examined in detail the justifications cited by the State as the reason for its actions, often combining the aims cited - such as the protection of health and morals and the protection of the rights and freedoms of others - into one reason. ${ }^{37}$ Hence, the Court has very rarely taken the step of rejecting the reasons given by States, and accepted that they were acting in pursuit of the stated aims. This has been the case even when the applicant may disagree. $^{38}$

(3) It 'must be necessary in a democratic society'. This means that any intervention must 'be a pressing social need', ${ }^{39}$ and that this intervention 'be proportionate to the legitimate aim pursued'. ${ }^{40}$ As for a 'democratic society', it is a society based on the principles of pluralism, tolerance and open-mindedness. ${ }^{41}$ For a State to have 'some' justification for taking the measures in question is obviously not sufficient as any interference must be 'necessary'. As regards the meaning of 'necessary', in Handyside v. the $U K$ the Court said that while

... it is not synonymous with "indispensable"... neither has it the flexibility of such expressions as "admissible", "ordinary", "useful", "reasonable" or "desirable". ${ }^{42}$ 
National authorities are granted a margin of appreciation when it comes to the matter of pressing social need. ${ }^{43}$ The reason for states having a margin of appreciation is on account of the fact that as some cases are very complex and sensitive, national authorities may be able to better evaluate each case in their own circumstances and ascertain the appropriate steps to take. ${ }^{44}$ Of course this margin of appreciation changes according to the existing circumstances, the issue in question and its antecedents. ${ }^{45}$

In addition to State parties having a margin of appreciation, they also have obligations within the framework of this right. In brief, while the margin of appreciation is being used States have to constantly fulfil the positive and negative obligations arising from the Convention. As a matter of fact, these obligations arise from Article 1 of the Convention. In this article, it is stipulated that High Contracting Parties shall secure to everyone in their jurisdiction the rights and freedoms defined in the Convention. Hence, it is the negative obligation of States to ensure there is no arbitrary interference in the exercise of this freedom. Thus, the fundamental purpose of Article 8 is to protect individuals against the arbitrary interference of public authorities.

There are also positive obligations incumbent on States to make sure that legal entities act respectfully towards each other. ${ }^{46}$ However, the meaning of the concept 'respect' here has not been defined by the Court. Hence, respect differs in each situation. While it has been defined according to circumstances what respect necessitates, States have a very broad margin of appreciation. The State should look to see whether a fair balance has been struck between the general interests of the individual and those of society. ${ }^{47}$ In brief, within the scope of positive obligations are the 'obligation to take measures' and 'obligation to be effective'. Examples of the obligation to take measures may be listed as follows: to enact legal provisions with regard to the issue in question, to carry out supervision and carry out a fair and unbiased investigation. Within the framework of these measures States should achieve effective outcomes. ${ }^{48}$

\section{European Court of Human Rights' current case law on the right to privacy}

As mentioned above all four main rights contained in Article 8 will not be covered in this article. Since the topic of this special edition is privacy, the ECtHR's case law regarding this right, what it encapsulates, in what circumstances it may be restricted and its relationship to other rights and freedoms will be examined.

As constantly expounded by the Court, 'private life' is a concept that is not easy to define. It includes matters of a personal nature, such as an individual's name and photo and a person's physical and psychological integrity. The main purpose of Article 8 of the Convention is to safeguard the development of an individual's personality and their relations with others without external interference. Hence, a person's area of interaction with others, even if it takes place in public, may possibly come within the scope of private life. $^{49}$

\subsection{Privacy and personal data}

Another significant right connected to privacy is 'an individual's right to protect his privacy'. While one aspect of the right to privacy is 'the right to be left alone', another 
is 'the right of an individual to control information about themselves', that is, 'the right to control personal data'. ${ }^{50}$

The Court considers the collection of data relating to an individual's private life and the holding and use of this data under Article 8. For instance, the case of S. and Marper v. the $U K$ involved two applicants. The first of these, Mr S., was arrested in January 2001 and charged with attempted robbery. He was eleven years old at the time. His fingerprints and DNA samples were taken but he was later found not guilty. Mr Marper, the second applicant, also had his fingerprints and DNA samples taken after being arrested in March 2001 and charged with harassment of his partner. Before a pre-trial review took place, Mr Marper and his partner repaired their relationship and in June 2001 the charges were dropped. Both Mr S and Mr Marper asked for their fingerprints and DNA samples to be destroyed, but the police refused. The Court found that the gathering and holding of personal data, even when it was not used, constituted a violation of Article $8 .^{51}$ This judgment highlights the limits of police powers as regards the gathering and holding of personal data for crime prevention, and the human rights implications of such retention by national authorities of DNA and fingerprint data for use on criminal identification databases. $^{52}$

After this judgment, in April 2010, the Crime and Security Act was introduced in the UK. However, after the change of government in May 2010, it was not enacted. In its place the Coalition Government brought in a new Protection of Freedoms Bill to bring the law in England and Wales into line with Scotland which was eventually adopted in May 2012 as the Protection of Freedoms Act and came into force at the end of 2013. In May 2011, the

Supreme Court declared that existing Association of Chief Police Officer (ACPO) guidelines relating to the retention of DNA, fingerprints and Police National Computer (PNC) records were unlawful on account of being incompatible with the ECHR. ${ }^{53}$ These developments are in fact a good example of the positive obligations pertaining to the measures High Contracting Parties should take in domestic law in line with judgments of the Court. Additionally, the Court considers the type of data collected and held, how it is used and potential effects. Thus, in Klass and others v. Germany the Court found that states could not justify the blanket monitoring of individuals on the grounds of espionage and counter terrorism. ${ }^{54}$ The Court stressed that interference with the rights of individuals must be subject to 'an effective control' and that the principle of proportionality was important. ${ }^{55}$ In its judgments the Court often refers to the Convention for the Protection of Individuals in connection with Automatic Processing of Personal Data (the Convention on Personal Data). ${ }^{56}$ In Article 1 of the above Convention, it is stated that its aim is the safeguarding of individuals' right to privacy with regard to automatic processing of personal data. This Convention incorporates provisions concerning the automatic processing of personal data. Article 2 of this Convention outlines the concept of personal data in the following way: 'any information relating to an identified or identifiable individual...' Although the Convention includes individuals, High Contracting Parties may, if they wish, also extend protection to legal entities. However, as this is dependent on the will of States, the fact that the Convention does not provide complete protection to legal entities is worthy of criticism. Moreover, according to paragraph $\mathrm{c}$ of this article this includes storing data, applying logical or mathematical processes to the data, making changes, deleting data, retrieval and distribution. Additionally, Article 3 makes clear that personal data processed by both the public and the private sector are within the scope of the Convention. Article 4 states: 
'Each State shall introduce the necessary provisions in its domestic law to protect the fundamental principles concerning data protection that are listed here'.

According to Article 5 data to be automatically processed must meet the following criteria:

(a) obtained and processed fairly and lawfully; (b) stored for specified and legitimate purposes and not used in a way incompatible with those purposes; (c) adequate, relevant and not excessive in relation to the purposes for which they are stored; (d) accurate and, where necessary, kept up to date; (e) preserved in a form which permits identification of the data subjects for no longer than is required for the purpose for which those data are stored.

Article 6 deals with sensitive data. Personal data concerning racial or ethnic origin, political opinions, religious or other beliefs, health and sexual life and criminal convictions are examples of special personal data.

The ECtHR takes its definition of personal data from Article 2(a) of the above Convention. ${ }^{57}$ According to the Court the protection of personal data is vital as regards a person exercising their right to respect for their private life. ${ }^{58}$ With regard to personal data the Court only takes into account individuals, in parallel with Article 2 of the Convention. For instance, the Court examined the claims of three Norwegian companies, in Bernh Larsen Holding AS and others v. Norway within the scope of 'right to respect for home' and 'right to respect for correspondence', not 'right to respect for private life' in Article 8(1) of the ECHR. In this way the Court did not allow legal entities to take advantage of the right to protection for personal data. ${ }^{59}$ This approach of the Court is open to criticism, as to accept legal entities as the subject of the right to respect for the home and correspondence, but to exclude them with regard to personal data does not seem consistent. Furthermore, in Court judgments the divulging of personal data, the sharing of this data with other organisations, not allowing access to information, the failure to correct erroneous personal data or the rejection of demands for personal data to be deleted, surveillance of telephones, revealing of names and addresses without the permission of the individual, the gathering of a person's data, their storage, use and the failure to allow the opportunity to disprove the veracity of data held have all been found to be in violation of Article $8 .^{60}$

When Court judgments are examined it is seen that the following are generally within the category of personal data: name, postal address, email address, IP address, bank accounts, medical data, GPS data, camera records, photographs, voice and blood records, fingerprints and DNA records. ${ }^{61}$ In other words, the Court separates data into two categories: specific and other data. Specific data relates to data referred to in Article 6 of the Convention on Personal Data such as 'racial origin', 'political opinions or religious or other beliefs', 'health or sexual life' or 'criminal convictions'. However, the issue here concerns other data not referred to in the article, but which may give a clue to a person's identity. The case law of the ECtHR needs to be examined in connection with this issue. In the Court's judgments the concept of personal data includes a person's profile, photographs, fingerprints, DNA profile, cell samples, personal medical data, voice, security number, home address and personal spending. ${ }^{62}$ Moreover, the Court identifies data according to it being either of a personal or public nature. That is, it considers a person's picture to be of a personal nature, while their political activities are classed as being of a public nature. 


\subsection{A person's photographs}

The Court makes the observation that a person's photographs identify them due to their unique character. Hence, they are important for a person's personal development. In the event of a well-known person's photographs being shared, this is particularly true and can have serious consequences. The reason for this is that it is important to find the middle ground between a person's reputation, as protected by Article 8, and Article 10, that safeguards freedom of expression. Regarding this point the Court poses these questions:

contribution to a debate of general interest; how well known is the person concerned and what is the subject of the report?; prior conduct of the person concerned; content, form and consequences of the publication; circumstances in which the photos were taken; and severity of the sanction imposed. ${ }^{63}$

Hence, every person, including people in the public eye, may reasonably expect that there will be safeguards in place to protect their private life. In Von Hannover $v$. Germany (no. 2), two German newspapers published photographs of members of a royal family on holiday. The Monaco royal family applied for an injunction to prevent further publication of the photographs in question, claiming that their right to private life had been violated. The German courts complied with the first Von Hannover ECtHR judgment, finding that two of the photographs contravened the right to privacy as they were not relevant to any public concern in the accompanying text. However, since the third photograph showed a Prince who was not well, and the health of members of the royal family was considered a matter of public concern, the ECtHR concluded there had been no violation of the Article 8 right to privacy in the ECHR. In coming to this conclusion, the Court adhered to the 5-point analysis it had outlined in the original Von Hannover case. The ECtHR concluded that, despite the photos featuring a public official, the accompanying articles were not relevant to the photographs. Hence, while the articles contained topics of public interest, two of the three photographs in the article did not, and that therefore, the domestic courts had not been wrong to prevent further publication of the two photographs in question. Secondly, the ECtHR found that the individuals in question were definitely public figures, on account of their political positions. So, once more the domestic courts had been right in their judgment. Thirdly, the ECtHR also concluded that, while the Applicants might have previously cooperated with the media, this did not mean they had given permission for the photographs in question to be published. Fourthly, the Court concluded that the photographs were not in essence offensive in nature. Lastly, the ECtHR judged that the domestic courts had not been wrong in their implementation of German law as regards harassment or other circumstances covering the taking of a photograph. Therefore, the domestic courts were not at fault as regards this part of their judgment. In conclusion, the ECtHR did not find that the German courts' implementation of the judgment in the previous Von Hannover case had been wrong. As a result, the ECtHR unanimously found there had been no violation of the Article 8 right to privacy in the ECHR. ${ }^{64}$

For Princess Caroline to be deemed a 'public figure' contrasts with the Court's earlier Von Hannover judgment of 2004 (Von Hannover (No.1)), when she was considered to be a 'private' individual, 'in whom the interest of the general public and the press was based solely on the membership of the reigning family, whereas she herself did not exercise any official functions'. ${ }^{65}$ In Von Hannover (No.2), the Court did not accept that the 
applicants could be deemed to be 'ordinary private individuals'. Therefore, 'they must be regarded as public figures'. However, the Court in the original case had not said Princess Caroline was an 'ordinary' private individual, instead saying she was a 'private' individual who was well known. Nevertheless, it appears that the scope of what constitutes a Convention-compliant publication has widened, even if it has become less clear. It does seem apparent that 'public figures' who wish to prevent the publication of photographs will find it more difficult, especially if they appear in articles that are considered to meet the general interest threshold. The ECtHR's conclusion that the decision of the German Court was within the margin of appreciation points to be an understanding that the middle ground between Article 8 and Article 10 will not on every occasion be as the court saw it in the first von Hannover judgment. Taking into consideration how a similar situation would have been addressed under English law, it is a matter of conjecture whether the judgment will have an effect in this country. Nevertheless, publishers may see the judgment as welcome recognition that the concept of privacy varies across Europe. ${ }^{66}$

Apart from this, in the circumstances of the police taking a person's photograph, what will happen? At this juncture the Court would examine whether the taking of photographs was a private or public matter and whether the photographs would be used deliberately or whether there was the possibility of making a public statement. ${ }^{67}$ In Friedl $v$ Austria a photograph of the applicant was taken by the police on a demonstration and a file relating to the applicant was concealed. The Court did not find a violation in this case, listing three reasons why: (1) since the police had not entered the applicant's home to take the photo, the 'inner circle' of his private life had not been intruded upon; (2) the photographs in question were of a public gathering, which the applicant participated in; (3) the reason for taking the photos was to record the nature of the demonstration and how those involved behaved to assist any subsequent investigation. ${ }^{68}$

The Court stated that the file in question might contain the person's criminal record and documents concerning the investigation in addition to the photographs taken by the police. ${ }^{69}$ In McVeigh v. the $U K$ the applicants, who were questioned, searched, fingerprinted and photographed under anti-terrorism legislation, claimed that the retention of relevant records was an interference in their private life. Initially, the Commission looked at the question of the taking and retention of fingerprints as part of investigative procedures. It reached the conclusion that some of the measures taken interfered with the applicants' private life, while keeping an open mind regarding whether solely the retention of fingerprints could be considered interference. The Court accepted the argument that the information was necessary for intelligence purposes, and conceded that there was a pressing social need to combat terrorism, a factor it considered to be more important than insignificant violations of the applicants' rights. ${ }^{70}$ The McVeigh judgment was an indication that the Court was prepared to be flexible regarding Convention norms in order to assist states in exceptional circumstances. ${ }^{71}$ In Murray v. the $U K$, after being arrested the applicant's personal details and photograph were recorded. This was deemed to be acceptable within the framework of the process of combatting terrorism. The Court found that all of the personal details recorded were relevant to legal procedures. This case gives the impression that the Court will examine the information recorded by the police and security forces as regards its nature and extent, allowing for the wide margin of appreciation which is usually applied. ${ }^{72}$ 
However, public authorities should take care not to abuse their powers on the grounds of protecting national security. The Court therefore wants to be satisfied that there are sufficient and effective assurances against all manner of abuse. For instance, in Leander $v$. Sweden the applicant was prevented from taking up a permanent post and his parttime employment was ended by the authorities on account of their seeing him as a security risk due to some secret information. ${ }^{73}$ The person in question made an application claiming a violation of his right to respect for his private life under paragraph 1 of Article 8, claiming that in addition to the information being concealed from him and used, he was not given the opportunity to refute the allegations against him. Although the Court accepted that the personnel control system had interfered in the applicant's private life, it pointed out, taking into consideration the existing measures to prevent abuse of the applicant's rights, that this system was necessary in a democratic society. In the twelve point list that the Court believed the Swedish government utilised to ensure sufficient protection against abuse, the Court attached importance to certain measures that aim to reduce the effects of personnel control procedures to the required minimum level. They are as follows:

(i) the existence of personnel control as such is made public through the Personnel Control Ordinance;

(ii) there is a division of sensitive posts into different security classes;

(iii) only relevant information may be collected and released;

(iv) a request for information may be made only with regard to the person whom it is intended to appoint;

(v) parliamentarians are members of the National Police Board;

(vi) information may be communicated to the person in question; the Government did, however, concede that no such communication had ever been made, at least under the provisions in force before 1 October 1983 ;

(vii) the decision whether or not to appoint the person in question rests with the requesting authority and not with the National Police Board;

(viii) an appeal against this decision can be lodged with the Government;

(ix) the supervision effected by the Minister of Justice;

(x) the supervision effected by the Chancellor of Justice;

(xi) the supervision effected by the Parliamentary Ombudsman;

(xii) the supervision effected by the Parliamentary Committee on Justice. ${ }^{74}$

This case indicates significant points pertaining to how control of the proper implementation of the system should be, and is for this reason important. Hence, the Court stated that it attached great importance to the fact that supervision of the system was given to independent bodies such as Parliament, the Justice Ministry, Parliamentary Ombudsman and Parliamentary Committee on Justice. $^{75}$

\subsection{Accessing personal data held by the state}

Another issue is whether a person whose data has been gathered by the public authorities has the right to access it. That said, the question also arises as to whether this can be extended to include the gathering of data by individuals and legal entities in addition to 
the data collection by public authorities. In the case of Gaskin $v$ the $U K$ the applicant was in public fostercare until reaching adulthood. After becoming an adult the applicant wished to access the file relating to his care, but his wish was rejected. The applicant argued his rights arising from Article 8 had been violated. The Court found that as the records in question related to a person's private and family life the case came within the framework of Article 8. The Court endeavoured to strike a balance between public interest (holding of social service records in a confidential system) and the private and family life of the individual. Hence, the Court stated:

persons in the situation of the applicant have a vital interest, protected by the Convention, in receiving the information necessary to know and to understand their childhood and early development. On the other hand, it must be borne in mind that confidentiality of public records is of importance for receiving objective and reliable information, and that such confidentiality can also be necessary for the protection of third persons. ${ }^{76}$

The Court holds that where such a system is in use the rights of the individual whowants to access records concerning his private and family life must be safeguarded in the event of the non-availability of a contributor to the records or their refusing permission. A system of this kind can only comply with the principle of proportionality if it ensures that an independent authority has the final say regarding the question as to whether access has to be allowed when a contributor fails to reply or refuses to give permission. In the case in question no such option existed for the applicant. The Court consequently found that the procedures followed did not respect Mr Gaskin's private and family life as enshrined in Article 8 of the Convention, and that a violation of that provision had occurred. ${ }^{77}$

The Gaskin case is seen as a notable victory for individuals who were put in public care at a young age. Such people are now granted limited access to their own records in order that they may learn about their childhood. However, the records of those who grew up in the care of the independent sector (the charities) are not covered by provisions contained in the Data Protection Act. Access to such files is only possible if these organisations grant permission. Nevertheless, the Gaskin case is considered a landmark case in the UK. The Data Protection Act has special provisions granting people previously in public care access to all manner of social services records, both electronically kept records and those in a paper-based filing system. Whereas prior to the judgment in the Gaskin case individuals could only access electronically stored data under Data Protection Act, computer systems and all other filing systems are now covered. The Information Commission was also established as an independent appeal body after this case. ${ }^{78}$

\subsection{Disclosure of personal data to third parties}

Is the revealing of personal data to third parties or the public a violation of Article 8? First of all, during the investigation and trial of a crime in the event of information relating to the suspect or accused what will happen? In Doorson $v$ the Netherlands the Commission stated that the showing by the police of a photograph of the applicant to a third party did not constitute a violation of Article 8. Firstly, this was because the photograph had been used for the purpose of investigation. Secondly, there was no public access to the photograph or other information concerning the applicant. And, finally, the photograph had been taken legally during an arrest procedure. ${ }^{79}$ It also found that the police informing 
the public was legitimate and since the incidents were a summary based on the truth no violation of Article 8 had taken place. ${ }^{80}$ This case is also a good example of the circumstances in which Article 8 is taken together with Article 6. The Court for the first time expressed its opinion on the relation between a fair trial and the rights of the witness. $^{81}$

Moreover, the sharing of personal data with third parties results in conflict between public interest and a person's privacy and in addition to this their honour and reputation. In other words, in practice the protection of the right to respect and dignity clashes with freedom of expression. Hence, the freedom of expression is safeguarded by Article 10. One of the criteria of restriction is the 'protection of the reputation and rights of others'. The ECtHR uses the following criteria in striking a balance between the right to respect for private life and freedom of expression: (i) Whether the information in question contributes to an argument that is in the public interest; (ii) Whether the subject of the news item or the person commented on is a public figure; (iii) Previous behaviour of the person in question; (iv) The content of the publication, its form and consequences; (v) The circumstances of the photograph taking; (vi) The severity of the sanction in question. ${ }^{82}$

It is important to state that the ECtHR only accepts penal sanctions/prison sentences in the case of hate speech or abetting a crime. Rather than penal sanction it considers measures taken during judicial procedures to be a sufficient legal remedy for attacks on a person's right to respect and reputation. ${ }^{83}$

It is not acceptable for the Convention to be interpreted in a way that requires individuals to put up with being the target of accusations of criminal activity without a factual basis levelled at them by State officials. The public reasonably expects the authorities to have concrete information regarding such accusations. ${ }^{84}$ An example of such a case is Egill Einarsson v. Iceland. The applicant, a well-known figure in Iceland, was called a 'rapist' on Instagram with an accompanying photograph. The Court found that such a comment could constitute interference with the private life of the applicant, since it was sufficiently serious. It stated that Article 8 should be interpreted in a way that even when public figures create controversy through their actions and public comments, they should not be expected to endure public accusations of violent criminal acts without a factual basis. ${ }^{85}$

As regards the Internet, the Court has stressed the importance of gauging the degree of seriousness. ${ }^{86}$ Millions of comments are posted online every day, and many of these comments can be considered offensive or even defamatory. However, most of these comments are trivial and with a limited publication and are therefore unlikely to seriously damage a person's reputation. In the case in question, the applicant argued that comments in a blog had damaged his reputation. In its deliberations the Court concurred with the national courts in their conclusion that while most of the comments in question were offensive, they were in reality only a form of 'vulgar abuse' frequently encountered on the Internet. Moreover, the Court considered that the more specific and potentially damaging allegations made would, in all probability, have been seen by those who read them as speculation which could not be taken literally. ${ }^{87}$

This judgment narrows the scope of freedom of expression by finding that a breach of the applicant's right to respect for his private life had been caused by the rejection of a defamation claim regarding his being called a 'rapist' online. The ECtHR made this judgment in spite of the importance attached by the domestic courts to the applicant's 
previous statements of a derogatory nature made against women, and the fact he was a well-known person who attracted public interest. One of the most worrying aspects of this judgment is that the Court did not take into consideration the character of online comment, and how they are understood by users. Such an observation was conspicuous by its absence in this judgment, but the Court has addressed this issue in other decisions. ${ }^{88}$

For instance, in Tamiz $v$. the $U K$, the Court dealt with the scope of the right to respect for private life as safeguarded by Article 8 relating to the freedom of expression of service providers such as Google Inc enshrined in Article $10 .{ }^{89}$ This case encapsulates an interesting example of conflict between Article 8 and Article 10, in that our personal information is on the internet, while, on the other hand, the public has a right to access information. In the present time individuals' personal information is frequently used on search engines like Google. Hence, this situation is in fact a classic example of personal data being shared with the entire public. This is also a good example of the 'right to be forgotten'. This right involves a person securing the prevention of access to their personal data. This right first became a topical issue in the Google v Spain judgment of the Court of Justice of the EU in 2014..$^{90}$

In Tamiz v. the UK, the ECtHR acknowledged that online communication is very often on the 'lower register of style', noting that the allegations made regarding the applicant would, in all likelihood, be understood by those reading them 'as conjecture which should not be taken seriously'. ${ }^{91}$ The Court in this judgment, too, neglected to properly acknowledge that domestic courts are best able to evaluate the meaning of comments in their social and cultural context. Nevertheless, this judgment broadens the scope of expression in stating that the UK's 'real and substantial tort' test is acceptable as regards striking a reasonable balance between the rights to freedom of expression and to personal reputation in the event of libelous statements being made in comments in online blogs. The test in question seriously restricts the degree of liability of blog hosting service providers. As a result, this also serves to reduce the possibility of businesses and other actors being put off by the fear of liability from creating websites that encourage the free debating of ideas. ${ }^{92}$

The case of M.L. and W.W. v. Germany addressed the question of internet archives featuring previously reported news for the first time at the ECtHR. The two applicants had been found guilty of murdering a popular German actor in 1991. In 2000, the media reported that they had made an application to have the case reopened. In 2007, the applicants went to court to attempt to have their names removed from those media reports, to protect their anonymity. After German Courts ruled against the applicants on the grounds that the right of the public to be informed of matters of public interest would then be violated, they went to the ECtHR. The Court remarked that the case incorporated conflict between two fundamental Convention rights: the applicants' right to respect for their private life under article 8 and the media's right to freedom of expression enshrined in article 10. The Court noted that the right to freedom of expression did not refer only to the right enjoyed by the specific media outlets in this case, but that it included the general freedom of the press to inform the public. The Court placed this case in the context of digital channels of communication having increased the risk for privacy. It examined the conflict between the two rights, weighing the relative importance of the contribution made by the articles to a general interest debate; the infamy of the applicants and the object of the report; M.L. and W.W's. previous behaviour towards the media; and 
the content, form and effect of the publication. The Court found that public interest in coverage of the crime and conviction existed, and also in the efforts to reopen the case, and that in general the public is interested in being informed about past events. The Court noted that to require the media to either remove personal information from their archives or no longer store their work would profoundly affect the freedom of expression. The Court also observed that on account of their murder conviction M.L. and W.W. were well known, and that this meant the public were likely to take an interest in developments. Furthermore, M.L. and W.W. had actively endeavoured to ensure press participation in their attempts to reopen the case. The Court mentioned relevant media reports, noting that the judicial decision had been accurately and objectively reported. It also noted that there was limited access to the reports, as they only appeared on news pages of websites which were only available to subscribers. Hence, the Court found that, having struck a balance between the two rights in question, there had been no violation of article $8 .{ }^{93}$

To sum up, the ECtHR endorsed the protection of media archives under article 10 of the Convention, and drew attention to the potentially serious effect of the request to remove personal details from articles in the archives of media organisations. ${ }^{94}$ In this judgment the right to be forgotten was touched upon, in that in the digital world the freedom of expression and data protection imperatives are interrelated. Therefore, both domestic courts and international courts have to be prepared to hand down judgments in an efficient and just manner. ${ }^{95}$

In Khadija Ismayilova $v$. Azerbaijan the Court found there had been a violation of Article 8 . The case involved the revealing of the applicant's personal data and financial and personal relationships in a press statement made by prosecution authorities, which the authorities claimed was part of a report regarding a criminal investigation. ${ }^{96}$ In J.S. v. the UK, the Court found a complaint by the applicant about personal data in a press statement made by the prosecution service was manifestly ill-founded. ${ }^{97}$ In this case the information in question did not include the applicant's name, age, school attended, or any other personal data, not going beyond what is normally issued to the media regarding court proceedings. ${ }^{98}$

In the case of Satakunnan Markkinapörssi Oy and Satamedia Oy v. Finland the Grand Chamber of the ECtHR found no contravention of the right to freedom of expression and information. ${ }^{99}$ Satakunnan Markkinapörssi Oy (Satakunnan) had, since 1994, been engaged in gathering tax data from the Finnish tax authorities and publishing data relating to individuals' taxable income and assets in the Veropörssi newspaper. There were other companies involved in such publishing in Finland, but not as much as Satakunnan. The Grand Chamber reached the conclusion there had been no violation of Article 10. It based its judgment on a narrow, public interest, interpretation of journalism and granted a wide margin of appreciation to the verdict of the domestic authorities. ${ }^{100}$ In fact, the Grand Chamber agreed with the domestic courts as regards the wide margin of appreciation it allowed in balancing the right to freedom of expression against the right to respect for a private life. The Grand Chamber was unable to conclude that en masse publication of tax data made a contribution to a public interest debate. It also considered that despite certain tax data being publicly accessible in Finland, it was necessary to distinguish between this situation and the way in which data was published by the companies, since this made the data 
accessible to an unintended extent. The Grand Chamber thus found that the restrictions imposed were legal and had the legitimate aim of protecting taxpayers' right to privacy. ${ }^{101}$

The above case narrows the concept of expression in that no breach of the right to freedom of expression was found in the event of domestic authorities and courts placing restrictions on the publication of taxation data in catalogues, even if the data was already accessible to the public. The judgment is puzzling in that it agrees with the domestic courts that the publication of data en masse in a journalistic file cannot be considered publication for journalistic purposes, or in the public interest. Moreover, the Court did not mention the fact that Finland has never made clear by means of administrative and judicial decisions, what the acceptable limits are as regards how and to what degree taxation data may be published in the country. The decisions merely stipulated that the applicants were not permitted to publish taxation data 'in the manner and to the extent that had been the case in 2002'. This leads to confusion as regards to which publication of this sort of data will come within the journalistic derogation from data protection law and, consequently, could have an alarming effect on data journalism. ${ }^{102}$

\subsection{Monitoring by CCTV or different technological equipment}

Control of personal information does not only occur through the internet, as surveillance of our movements can also be carried out in public spaces by CCTV or other technological equipment. The question that arises now is what will happen to the footage recorded by video surveillance of public spaces. The Court generally considers these circumstances under Article 8.

In Peck v. the UK, a Brentwood Borough Council CCTV camera filmed the applicant in a street only seconds after he had cut his wrists with a knife in an attempt to commit suicide. Several months later, the Council used two photographs from that CCTV footage in a published article concerning the role of CCTV in crime prevention. In the photographs the applicant's face was not obscured, whereas in the CCTV footage that was also shown on regional television the applicant's face was concealed at the request of the Council. The applicant went to court to seek a judicial review of the Council's decision to use the CCTV footage. After his application was rejected and the decision ratified by the Court of Appeal he applied to the ECtHR. ${ }^{103}$ After the release of the CCTV footage, the actions of the applicant were made accessible to a much larger number of people, vastly more than being seen by a passerby or a security observation, and to an extent the applicant could never have foreseen. Hence, the Council's actions were a grave interference with his right to respect for private life. The Council could not justify its disclosure without the permission of the applicant, or failing to take reasonable steps to ensure his identity was concealed. The applicant's later appearances on the media did not reduce the serious implications of the interference. Since the publishing of the footage by the Council was not sufficiently safeguarded it constituted a disproportionate interference with the applicant's rights under Article 8. In brief, this case is an example of the ECtHR considering that incidents which occur in public can still fall within the scope of a person's private life and, therefore, an individual can have areasonable expectation of privacy. ${ }^{104}$ 
The Court also stated that the publication of photographs taken by the police or public authorities of persons in custody without their consent constitutes a violation of Article 8. However, in the case of the disclosure of photographs of a suspected terrorist, a breach of Article 8 was not found on account of the state being granted a broader margin of appreciation. ${ }^{105}$

State monitoring of communications is an issue that causes fierce debate in modern times. Although State public authorities are allowed a margin of appreciation on the question of evaluating policy in this field, they are entitled to carry out unlimited covert surveillance of persons within their jurisdiction. Nevertheless, the Court has emphasised that States cannot use any measures they deem legitimate on the grounds of fighting espionage and terrorism; rather, adequate and effective measures to prevent abuse must be applied regardless of the type of surveillance used. ${ }^{106}$ The clandestine monitoring of citizens is only acceptable when it is absolutely necessary in order to protect democratic institutions. ${ }^{107}$ There must be concrete reasons for all procedures utilised, and they must be proportionate to the legitimate aims pursued. ${ }^{108}$

In Weber and Saravia v. Germany the first applicant, Ms. Gabriele Weber, a German citizen resident in Montevideo, the capital of Uruguay, was a freelance journalist who investigated issues subject to surveillance by the Federal Intelligence Service (armaments, drug trafficking, etc.). As part of her job, she travelled all over Europe. The second applicant, Mr. Cesar Richard Saravia, was a Uruguayan national living in Montevideo, who was working for Montevideo City Council. When Ms. Weber was on assignments, Mr Saravia took phone messages for her, forwarding them to her. The applicants claimed that the Fight against Crime Act in Germany allowed surveillance of telecommunications without any concrete justification, using secret passwords. They argued that such monitoring was used to prevent journalists from doing effective research regarding sensitive issues covered by the above Act. The Court found that the interference in question was 'necessary in a democratic society' in order to meet the respondent State's aim, since the surveillance had sufficient safeguards against misuse. Strict conditions relating to the communication and use of personal data existed, restricting the utilisation of information obtained to what was necessary. Moreover, personal data was destroyed to prevent abuse, and individuals under surveillance were informed as soon as possible of any restriction imposed on the confidentiality of their communications. ${ }^{109}$ Although the Court has yet to make a clear judgment regarding whether personal data obtained from foreign intelligence services leads to a breach of Article 8, as can be seen in this judgment, a state's national security interests are given priority over the rights of individuals. Although of course this does not mean that states can do anything in the name of national security, as the Court points out that domestic legislation must contain sufficient safeguards in law to protect individuals and to avoid abuse of power. In this context, this is a significant judgment.

The ECtHR issued a long-awaited judgment in Big Brother Watch and others $v$. the $U K .{ }^{110}$ This judgment came in the first mass electronic monitoring case against the UK, which examined the issue of mass interception of communications. This judgment was the conclusion of a protracted challenge to the espionage powers possessed by Britain, which had been exposed by Edward Snowden in 2013. The Court found that these powers, which enable the UK to carry out mass surveillance, constituted a violation of the rights to privacy and freedom of expression. Firstly, the Court found that Britain's use of mass interception violated the right to privacy enshrined in Article 8 of the 
ECHR on account of the 'absence of robust independent oversight of the selectors and search criteria used to filter intercepted communications', ${ }^{111}$ and the freedom of expression under Article 10. It also found that these rules were illegal, since interception of communications data was a serious violation of privacy. Finally, the Court found that allowing mass interception of communications conflicted with the principle of proportionality as regards interference only being of a degree necessary in a democratic society. The Court added that any interception must be in accordance with the six minimum requirements cited in Weber and Saravia v. Germany, to reduce the risk of abuse of power. The Regulation of Investigatory Powers Act 2000 (RIPA) allows the security services to scrutinise 'related communications' data, with no limitations attached, which was not considered to be sufficient protection and therefore constituted a violation of Article 8 of the ECHR. Although this was certainly an important victory for human rights organisations, it is also true that the judgment was based the on the rather technologically outdated principles established more than a decade before in Weber and Saravia. The surveillance capabilities of security services in Europe are now many times greater. Digital monitoring is now carried on indiscriminately and en masse. Hence, individuals who have absolutely nothing to do with terrorism and organised crime are more likely to be affected by mass interception of data. There may well be widespread disgruntlement that the Court did not establish more updated principles to cope with the latest digital bulk monitoring systems. ${ }^{12}$

\subsection{Disclosure of medical data and confidentiality}

According to the Court, it is necessary for there to be respect for the privacy of medical data. This requirement is not solely to do with an individual's privacy, but also concerns confidence in the medical profession and health services in general. ${ }^{113}$ Hence, since the disclosure of a person's medical data will sometimes lead to individuals applying for medical assistance, the Court has noted that in these circumstances disclosure will endanger the health of a person or community. ${ }^{114}$ For instance, in Z. $v$ Finland the applicant claimed the disclosure of medical data including an HIV situation at a rape trial constituted a violation of Article 8. According to the Court, the rights of a patient and of the community in general regarding the protection of medical data may be of less importance than the public benefit of the investigation of a crime and the public nature of the resulting trial. Every case must be evaluated according to its unique character and the state's margin of appreciation be taken into consideration. In this case the Court held that the disclosure of the witness's medical records was 'necessary' in the meaning of paragraph 2 of Article 8. However, the Court ruled that no legitimate purpose had been served by the disclosure of the witness's name and HIV status in the appeal court judgment. The Court reached the conclusion that Article 8 of the Convention had been breached on account of court files containing details of the applicant's medical records (HIV status) being made public ten years later, given the possibility of the person still being alive. ${ }^{115}$ While this case is important for the emphasis it placed on the confidentiality of personal data, the principle of respect for private life is not solely the responsibility of organisations or companies. States are responsible for data protection, too. Accountability should be allotted and distributed to all relevant entities at a national level. ${ }^{116}$ 
Additionally, the disclosure by medical institutions of medical data to journalists and a prosecutor's office, and the collection of a patient's medical records by a body tasked with supervising the quality of medical care were also found to have violated the right to respect for private life. ${ }^{117}$ However, the provision of medical data to social security authorities is important as regards a person benefitting from insurance, therefore it is necessary for insurance companies to have access to the person's medical history. Furthermore, since in the event of the insurance companies disclosing the medical data in question legal action may result, the existing measures were considered to be proportional and, hence, no violation of Article 8 had taken place. ${ }^{118}$

According to the Court the gathering of DNA samples also comes within the scope of the right to privacy. Moreover, the collection and retention of cellular material, and storing of DNA profiles extracted from it, has been categorised as interference with the right to respect for privacy as enshrined in the Convention. ${ }^{119}$ However, this prohibition is not a blanket one, as it does not automatically include the taking and storing of DNA profiles of those persons convicted of crimes, for the purpose of use in any criminal trials that may take place in the future. As mentioned above, unless interference of this nature is deemed to be 'in accordance with law', in that it can be justified as being a legitimate aim under paragraph 2 of Article 8 and as being 'necessary in a democratic society', then it will be considered a violation of Article 8. ${ }^{120}$

The ECtHR, while widening the boundaries of Article 8, is also indicating that this freedom is not unconditional. Hence, when considering the negative and positive obligations that states have relating to the restriction of this right, one must carefully apply the three stage test. In other words, in order to avoid a violation of Article 8, there must be a legal provision, which must be implemented in pursuit of a legitimate aim and be proportionate and necessary in a democratic society. If this is not the case, then there will be a possibility that the principle of proportionality may be breached, constituting a violation of Article 8.

Furthermore, since the right to protection of personal data is not an absolute right, a balance needs to be struck between both other rights in the Convention and other legal interests in Article 8. Hence, this right is one that is linked to other articles in the Convention. For instance, Article 10. Several cases have been mentioned above in which this right is connected to the freedom of expression. Article 8 has also been interpreted in combination with Article 14, that prohibits discrimination, in numerous cases. This is particularly true in cases concerning same sex couples or gender-based discrimination. Apart from this, connections have also been made with interference with home relating to states' positive obligations with regards to property rights (Article 1 of Protocol No. 1) and the right to life (Article 2). In Kolyadenko and Others $v$. Russia, the ECtHR found that the City of Vladivostock Administration and the Promorskiy Regional Administration of Russia had contravened Articles 2 and 8 of the Convention. This case involved the authorities failing in a duty to maintain the Pionerskaya River and not introducing the necessary legal and remedial measures to prevent flooding. These failures led to serious damage to property (right to property) and endangered the lives (right to life) of Vladivostock residents. Articles 2 and 8 enshrine the rights to life and to respect for the home. The Court concluded that Article 2 had been violated both substantively and procedurally, on account of the State failing to make an adequate judicial response to the claims of violation of the 
right to human life. The Court found the Russian State to be responsible for the damages suffered by residents as a result of the violations. ${ }^{121}$

Finally, as regards Article 8 of the ECHR, clear and detailed legal provisions are required that set forth the rules and guarantees governing the circumstances under which personal data may be gathered, the period of retention, how they may be used and in what circumstances they will be destroyed. ${ }^{122}$ For instance, in the context of the retention of personal data, for there to be no difference in the period of retention of criminal records for those convicted of a crime, without differentiating the nature of the offence, and for there to be no legal provision relating to the deletion of these records constitutes a violation of Article 8 of the Convention. ${ }^{123}$ The retention for indefinite periods of the fingerprints, cellular samples and DNA profiles of applicants who have been acquitted on criminal offences is a violation of Article 8 . Hence, this situation constitutes a contravention of the principle of not holding personal data for longer than is necessary. Individuals have the right to access information in records relating to them held by public authorities. The lack of recognition for such a right or the failure to ensure access within a reasonable time may also be considered a violation of Article 8. ${ }^{124}$ According to the ECHR, the widespread and reckless use of modern technological techniques in the criminal justice system jeopardises the right to respect for private life and significantly undermines the protection provided by Article $8 .{ }^{125}$

\section{Conclusion}

To set down a precise definition and explanation of the concept of private life is virtually impossible. Freedom of ideas, expression, religion and conscience in social life also come within the scope of this freedom. Even accepting the difficulty in defining the concept of private life and establishing its limits does not mean it does not exist. It is undoubtedly one of the most fundamental of human rights and is crucial in the safeguarding of human dignity and autonomy. The right to privacy is the right of an individual to have a private life without encroachment. This freedom therefore provides safeguards against interference of an arbitrary and unwarranted nature by either the state or non-state actors. States have negative and positive obligations, one of which is to ensure that effective mechanisms are implemented to protect this freedom of individuals. These obligations have been enshrined in international human rights law and in the domestic legislation of many countries.

The ECtHR in particular has not only reached judgments on hundreds of applications on this subject, it has also made many points with reference to private life. Hence, with technological developments, changes are taking place in our social relations. As a result, as mentioned above, the definition and scope of private life becomes even more difficult. Therefore, the case law of the ECtHR is illuminating. As pointed out in this article, Article 8 of the Convention also incorporates rights relating to family, home and communication, apart from private life. Both states and large companies occasionally interfere in the rights of others by using their powers in an arbitrary way. In particular in the digital world it is difficult to determine the boundaries of private life. The dimensions of interference in this sphere also vary widely. However, in spite of all these difficulties, contracting states should not allow their own authorities or others to violate this freedom. Furthermore, they have a duty to take effective measures to prevent infringements of these rights, as these are their negative and positive obligations. Of course, this right is not without restrictions. Any interference must have a legal basis, permission and comply with the principle of proportionality. Hence, in recent times the 
UN, ECtHR and EU mechanisms have brought in provisions (e.g. GDPR) as part of efforts to prevent arbitrary and unwarranted interference in this right. However, in spite of these developments, when considering that in today's world the personal data of one in ten people has been violated and more than 70 states have yet to introduce legal measures to safeguard this right, it is clear that sufficient remedies must be brought in as soon as possible at the international and national level.

As a result, Article 8 is not a right that can be solely interpreted in relation to the right to privacy. It plays a significant role in an individual's personal development. For instance, it relates to the enhancement of identity and personality. ${ }^{126}$ This right is also connected to other rights and freedoms safeguarded by the Convention. It is consequently a very important and fundamental right and freedom. It is thus incumbent on states that have yet to enact legal provisions to introduce necessary and effective measures as soon as possible, an obligation they are required to fulfil in accordance with international mechanisms.

\section{Notes}

1. Ali Korkmaz, 'Insan Haklari Baglaminda Ozel Hayatin Gizliligi ve Korunmasi' [Right to Privacy and Its Protection in the Context of Human Rights], KMU Sosyal ve Ekonomik Arastirmalar Dergisi 16 (2014): 99.

2. C. T. Onions, G. W.S. Friedrichsen and R. W. Burchfield, Oxford Dictionary of English Etymology (Oxford: Oxford University Press 1966), 711.

3. Yasar Salihpasaoglu, 'Ozel Hayatin Kapsami: Avrupa Insan Haklari Mahkemesi Ictihatlari Isiginda Bir Degerlendirme' [The Scope of Right to Privacy: An Evaluation in light of Eurp= pean Court of Human Rights' Case Law], Gazi Universitesi Hukuk Fakultesi Dergisi XVII (2013): 233.

4. Pal Fejos, Ethonology of the Yagua (New York: Viking Fund Publication, 1943); Barrington Moore, Privacy: Studies in Social and Cultural History (New York: Routledge, 1984); Also see Salihpasaoglu, pp. 228-229.

5. James R. Michael, Privacy and Human Rughts: An International and Comparative Study, with Special Reference to Development in Inforation Technology (Paris: UNESCO, 1994), p. 15; Also see Salihpasaoglu, p. 229.

6. Guclu Akyurek, Ozel Hayatin Gizliligini Ihlal Suclari, Cesitli Hukuk Dallarinda Ozel Hayatin Gizliliginin Korunmasi [A Violation of Right to Privacy, The Protection of Right to Privacy in Various Law Branches] (Ankara: Seckin Publication House, 2011), 105-8; Also see Korkmaz, 'Insan Haklari Baglaminda Ozel Hayatin Gizliligi ve Korunmasi', 100.

7. Niemietz v. Germany, 13710/88, 16.12.1992, para. 29.

8. Arthur Miller, Assault on Privacy: Computers, Data Banks and Dossiers (Michigan: The University of Michigan Press, 1971); Also see Salihpasaoglu, 'Ozel Hayatin Kapsami', 234.

9. Julie C. Innes, Privacy, Intimacy and Isolation (Oxford: Oxford University Press, 1992), 3; Also see Salihpasaoglu, 'Ozel Hayatin Kapsami', 234.

10. Ibid, 235-6.

11. Human Rights Council Resolution, A/HRC/RES/34/7.

12. Human Rights Council, 'Report of the Special Rapporteur on the right to privacy', A/HRC/ 37/62, 2018, p. 14.

13. Korkmaz, 'Insan Haklari Baglaminda Ozel Hayatin Gizliligi ve Korunmasi', 102.

14. Costello-Roberts v. the United Kingdom, 13134/87, 25.03.1993, para. 36. 
15. Niemietz v. Germany, 13710/88, 16.12.1992, para. 29.

16. See Council of Europe, Guide on Article 8 of the European Convention on Human Rights (Strasbourg: Council of Europe, 2019); See also e.g. Pretty $v$ the United Kingdom, 2346/02, 29.04.2002; Peck $v$ the United Kingdom, 44647/98, 28.01.2003; Von Hannover v Germany (No. 2), 40660/08, 60641/08, 07/07/2012; Barbulescu v. Romania (GC), 61496/08, 05.09.2017; Satakunnan Markkinaporssi Oy and Satamedia Oy v Finland (GC), 931/13, 27.06.2017.

17. Ursula Kilkelly, The Right to Respect for Private and Family Life: A Guide to the Implementation of Article 8 of the European Convention on Human Rights (Strasbourg: Council of Europe, 2003), 16.

18. Johnston and others $v$ Ireland, 9697/82, 18.12.1986.

19. Berrehab $v$ the Netherlands, 10730/84, 21.06.1998.

20. $X, Y$ and $Z v$ the United Kingdom (GC), 21830/93, 22.04.1997.

21. Vallianatos and Others v. Greece [GC], 29381/09 and 32684/09, ECHR 2013, paras. 73-74; X and Others v. Austria [GC], 19010/07, ECHR 2013, para. 95.

22. See Gulay Arslan Oncu, Ozel Yasama ve Aile Yasamina Saygi Hakki [Right to Private and Family Life] (Ankara: Anayasa Mahkemesi Yayinlari, 2019), 125.

23. K. and T. v. Finland [GC], 25702/94, 12.07.2001, para. 150.

24. Giacomelliv Italy, 59909/00, 02.11.2006, para. 76.

25. Khatun and 180 others $v$. the United Kingdom, 38387/97, EComHR Admissibility Decision, 01.07.1998, para. 1 .

26. Gillow v. the United Kingdom, 9063/80, 24.11.1996, para. 46; Khatun and 180 others v. the United Kingdom, 38387/97, EComHR Admissibility Decision, 01.07.1998, para. 1.

27. Niemietzv. Germany, 13710/88, 16.12.1992, para. 29; Chapman v. the United Kingdom [GC], 27238/95, 18.01.2001, para. 74; Demades v. Turkey, 16219/90, 31.07.2003, para. 45.

28. O'Rouke v. the United Kingdom, 39022/97, 26.06.2001, para. 3.

29. Kilkelly, The Right to Respect for Private and Family Life, 19.

30. Copland v. the United Kingdom, 62617/00, 03.04.2007, para. 41; Margareta and Roger Andersson v. Sweden, 12963/87, 25.02.1992, para. 72.

31. Oncu, Ozel Yasama ve Aile Yasamina Saygi Hakki, 34.

32. Bernh Larsen Holding AS and Others v. Norway, 24117/08, 14.03.2013, para. 106.

33. Schönenberger and Durmaz v. Switzerland, 11368/85, 20.06.1988.

34. Oncu, Ozel Yasama ve Aile Yasamina Saygi Hakki, 154.

35. Kilkelly, The Right to Respect for Private and Family Life, 25.

36. Silver and Others $v$. the United Kingdom, 5947/72;6205/73;7052/75;7061/75; 7107/75; 7113/ $75 ; 7136 / 75,25.03 .1983$, para. 90.

37. Open Door Counsel- ling v. Ireland, 14234/88, 29.10.1992.

38. Kilkelly, The Right to Respect for Private and Family Life, 30.

39. Olsson v. Sweden, 10465/83, 24.03.1988, para. 67.

40. Coster v. the United Kingdom, 24876/94, 18.01.2001, para. 104; Jane Smith v. the United Kingdom, 25154/94, [GC], 18.01.2001, para. 54.

41. Handyside v. the United Kindgom, 5493/72, 07.12.1976, para. 49.

42. Ibid., para. 48.

43. Ibid., 11.

44. Olsson v. Sweden (No. 2), 13441/87, 30.10.1992, para. 91.

45. Kilkelly, The Right to Respect for Private and Family Life, 32.

46. Council of Europe, Guide on Article 8 of the European Convention, 8.

47. Kilkelly, The Right to Respect for Private and Family Life, 21.

48. Beganovic v Crotia, 46423/96, 25.06.2009; Storck v Germany, 61603/00, 16.06.2005.

49. Von Hannover v. Germany (no. 2) [GC], 40660/08 and 60641/08, 07.02.2012, para. 95.

50. Oncu, Ozel Yasama ve Aile Yasamina Saygi Hakki, 79.

51. S. and Marper v. the United Kingdom [GC], nos. 30562/04 and 30566/04, ECHR 2008.

52. Liz Heffernan, 'DNA and Fingerprint Data Retention: S and Marper v United Kingdom', European Law Review 34, no. 3 (2009): 491-504. 
53. R v The Commissioner of Police of the Metropolis [2011] UKSC 21: See also GeneWatch UK, 'The Marper Case', http://www.genewatch.org/sub-563146 (accessed January 18, 2020).

54. Klass and others v. Germany, Series A no. 28, 06.09.1978.

55. See Salihpasaoglu, footnotes 104, 116, 117, 120.

56. Convention for the Protection of Individuals with regard to Automatic Processing of Personal Data, Strasbourg, 28.I.1981.

57. Amann v. Switzerland [GC], 27798/95, 16.02.2000, para. 65.

58. Z. v. Finland, 22009/93, 25.02.1997, para. 95.

59. Bernh Larsern Holding AS and Others v. Norway, 24117/08, 08.07.2013, para. 107.

60. E.g. M. S. v. Sweden, 20837/92, 27.08.1997; Gaskin v. the United Kingdom, 10454/83, 07.07.1989; Leander v. Sweden, 9248/81, 26.03.1987; Amann v. Switzerland, [GC], 27798/ 95, 16.02.2000, para. 65; S. and Marper v. the United Kingdom, [GC], 30562/04 30566/04, 04.12.2008, para. 41; Rotaru v. Romania, [GC], 28341/95, 04.05.2000, para. 43.

61. E.g. P.G. and J.H. v. the United Kingdom, 44787/98, 25.09.2001; Vetter v.France, 59842/00, 31.05.2005; Wisse v. France, 71611/01, 20.12.2005; L. H. v. Latvia, 52019/07, 29.04.2014.

62. Salihpasaoglu, 'Ozel Hayatin Kapsami', 245.

63. Von Hannover v. Germany (no. 2), paras. 108-113; Axel Springer AG v. Germany [GC], 39954/08, 07.02.2012, paras. 89-95; See also Council of Europe, Guide on Article 8 of the European Convention, 34.

64. Global Freedom of Expression, 'Von Hannover v. Germany (no. 2)', https:// globalfreedomofexpression.columbia.edu/cases/von-hannover-v-germany-no-2/ (accessed January 18, 2020).

65. Von Hannover v. Germany (no. 1), 59320/00, 24.06.2004, para. 72.

66. 5rb Media and Communications Law, 'Von Hannover v. Germany (no. 2)', https://www.5rb. com/case/von-hannover-v-germany-2/ (accessed January 18, 2020).

67. Kilkelly, The Right to Respect for Private and Family Life, 34.

68. Friedl v. Austria, Comm. Rep., 15225/89, 19.05.1994, p. 20.

69. Kilkelly, The Right to Respect for Private and Family Life, 35-7.

70. McVeigh, O'Neill and Evans v. the United Kingdom, 8022/77, 8025/77, 8027/77, 18.03.1981, DR 24, p. 15.

71. Edward Crysler, 'Brannigan and Mcbride v. U.K.: A New Direction on Article 15 Derogations Under the European Convention on Human Rights?' Revue Belge De Droit International 2 (1994): 609.

72. Murray v. the United Kingdom, 18731/91, 28.10.1994.

73. Leander v. Sweden, 9248/81, 26.03.1987, paras. 59-60.

74. Ibid., para. 62.

75. Ibid., para. 65 .

76. Gaskin v the United Kingdom, para. 49.

77. Ibid., para. 49.

78. Revolvy, 'Gaskin v United Kingdom', https://www.revolvy.com/page/Gaskin-v-UnitedKingdom (accessed January 18, 2020).

79. Doorson v. the Netherlands, 29.11.1993, DR 75, p. 231.

80. Kilkelly, The Right to Respect for Private and Family Life, 39.

81. A. Beijer, and A.M. van Hoorn, 'Report on Anonymous Witnesses in the Netherlands', https://webcache.googleusercontent.com/search?q=cache:IbmAGHVHRJJ:https://dspace. library.uu.nl/bitstream/handle/1874/43921/b25.pdf\%3Fsequence\%3D1 $\$$ \&cd=8\&hl=en\&ct= clnk\&gl=nl (accessed on January 18, 2020), 547.

82. Oncu, Ozel Yasama ve Aile Yasamina Saygi Hakki, 93-4.

83. Tolstoy Miloslavsky v. the United Kingdom, 18139/91, 13.07.1995.

84. Jishkariani v. Georgia, 18925/09, 20.09.2018, paras. 59-62.

85. Egill Einarsson v. Iceland, 24703/15, 07.11. 2017, para. 52; See also Council of Europe, p. 35.

86. Tamiz v. the United Kingdom, 3877/14, 19.09.2017, paras. 80-81.

87. Council of Europe, Guide on Article 8 of the European Convention, 36. 
88. GlobalFreedom of Expression, 'EgillEinarssonv. Iceland', https://globalfreedomofexpression. columbia.edu/cases/einarsson-v-iceland/ (accessed January 18, 2020).

89. Tamiz v. the United Kingdom, paras. 83-84.

90. Case C-131/12, Google Spain SL, Google Inc. v. Agencia Española de Protección de Datos (AEPD), Mario Costeja González, Judgment of the Court (Grand Chamber), 13.05.2014, EU: C: 2014: 317

91. Tamiz v. the United Kingdom, para. 81.

92. Global Freedom of Expression, 'Tamiz v. United Kingdom', https://globalfreedomofexpression. columbia.edu/cases/tamiz-v-united-kingdom/ (accessed January 18, 2020).

93. M.L. and W.W. v. Germany, 60798/10 and 65599/10, 28.01.2018, paras. 91, 97, 116.

94. Global Freedom of Expression, 'M.L. and W.W. v. Germany', https://globalfreedomofexpre ssion.columbia.edu/cases/m-l-w-w-v-germany/ (accessed January 18, 2020).

95. Oleg Soldatov, 'M.L. AND W.W. v. Germany: Recent Developments in Judicial Balancing of Privacy and Free Speech Online', 2018, https://www.rcmediafreedom.eu/Tools/LegalResources/M.L.-AND-W.W.-v.-Germany-Recent-Developments-in-Judicial-Balancing-ofPrivacy-and-Free-Speech-Online (accessed January 18, 2020).

96. Khadija Ismayilova v. Azerbaijan, 65286/13 and 57270/14, 10.01.2019, paras. 142-150.

97. J.S. v. the United Kingdom, 445/10, 03.03.2015.

98. Council of Europe, Guide on Article 8 of the European Convention, 40.

99. Satakunnan Markkinapörssi Oy and Satamedia Oy v. Finland, 931/13, 27.06.2017.

100. Dirk Voorhoof, 'No journalism exception for massive exposure of personal taxation data', 2017, https://strasbourgobservers.com/2017/07/05/no-journalism-exception-for-massiveexposure-of-personal-taxation-data/\#more-3801 (accessed January 18, 2020).

101. Global Freedom of Expression, 'Satakunnan Markkinapörssi Oy and Satamedia Oy v. Finland', https://globalfreedomofexpression.columbia.edu/cases/case-satakunnan-markkinaporssi-oysatamedia-oy-v-finland/ (accessed January 18, 2020).

102. Ibid.

103. Peck $v$ the United Kingdom, para. 57-63.

104. 5rb Media and Communications Law, 'Peck v United Kingdom',https://www.5rb.com/case/ peck-v-united-kingdom/ (accessed January 18, 2020).

105. Murrayv. the United Kingdom, 14310/88, 28.10.1994, para. 93; Segerstedt-Wiberg and others v. Sweden, 62332/00, 06.09.2006, para. 88.

106. Weber and Saravia v. Germany, 54934/00, 29.06.2006, para. 49-50.

107. Weber and Saravia v. Germany, para. 42; Rotaru v. Romania [GC], 28341/95, 04.05.2000, para. 47; Weber and Saravia v. Germany, para. 78.

108. Segerstedt-Wiberg and Others v. Sweden, para. 88.

109. Global Freedom of Expression, 'Weber and Saravia v. Germany', https://globalfreedomofe xpression.columbia.edu/cases/weber-saravia-v-germany/ (accessed January 18, 2020).

110. Big Brother Watch and others v. the United Kingdom, 58170/13, 62322/14 and 24960/15 [2018] ECHR 722.

111. Ibid, para. 347.

112. Reed Smith, 'ECtHR rules on UK mass surveillance under RIPA', https://www.lexology.com/ library/detail.aspx?g=7a2e807c-ac9b-4fa9-b751-7deee591b6d9 (accessed January 18, 2020).

113. Council of Europe, Guide on Article 8 of the European Convention, 41.

114. Kilkelly, The Right to Respect for Private and Family Life, 39-40.

115. Zv. Finland, 22009/93, 25.02.1997, para. 96; See also Kilkelly, Ibid., 40.

116. Antonella Galetta and Paul de Hert, 'A European Perspective on Data Protection and the Right of Access', in The Unaccountable State of Surveillance: Exercising Access Rights in Europe, eds. Clive Norris and others (New York: Springer, 2017), 32.

117. Mockutè v. Lithuania, 66490/09, 27.02. 2018, para. 95.

118. $M V v$ vweden, 20837/92, 27.08.1997.

119. S. and Marper v. the United Kingdom [GC], 30562/04 and 30566/04, 04.12.2008, para. 71-77; Van der Velden v. the Netherlands (dec.), no. 29514/05, ECHR 2006-XV; W. v. the Netherlands (dec.), no. 20689/08, 20.01.2009. 
120. Peruzzo and Martens v. Germany (dec.), nos. 7841/08 and 57900/12, 04.06.2013, paras. 42 and 49.

121. Kolyadenko and Others v. Russia, 17423/05, 28.02.2012, para. 216.

122. M. M. v. the United Kingdom, 24029/07, 13.11.2012, para. 199.

123. Aycaguer v. France, 8806/12, 22.06.2017, paras. 34, 38, 44, 45.

124. Haralambie v. Romania, 21737/03, 27.10.2009.

125. Oncu, p. 85.

126. Sloot, Bart van der, 'Privacy as Personality Right: Why the ECtHR's Focus on Ulterior Interests Might Prove Indispensable in the Age of Big Data', Utrecht Journal of International and European Law 31, no. 25 (2015): 44. 